\title{
PROBING THE DECLINING SIGNIFICANCE OF GOVERNMENT AND PHILANTHROPY IN NIGERIA: RELIGION AS A REFUGE?
}

\author{
Mike Omilusi ${ }^{1}$
}

\section{Introduction and Background to the Study}

In Nigeria, as in many other parts of Africa, democracy has had a chequered history, and remains fragile. Part of the explanation has been that dominant political forces constantly undermine the effective involvement of the people as key players in the processes of governance. The character of the Nigerian state has been exploited by the operators of state affairs to achieve sectional interests. Managers of state affairs have often times assumed the position of the state thereby rendering the state paralyzed and in fact subjecting it to their whim and caprice. The situation became more pathetic under military regimes, with their unitary, hierarchical and commanding nature largely affecting the operation of the Nigerian state.

It is affirmed that new democracies, such as Nigeria, face an immediate challenge of survival as governments 'struggle to maintain constitutional rule and electoral processes that are threatened by conflicts, military coups, or aspiring dictators waiting in the wings' (Lewis 2006, cited in Yagboyaju 2015, I66). In addition, all democracies are confronted by several other important tasks. These include 'broadening personal freedoms; encouraging genuine political participation; promoting the accountability of leaders; resolving conflicts; advancing a general rule of law; and building efficient and effective public institutions' (Lewis 2006, cited in Yagboyaju 2015, 166). As posited by Yabi (20I5), many Africans have excellent reasons to doubt the usefulness of the "democracy" that was so enthusiastically touted to them at the turn of the I990s. Threatened by a wide variety of violent conflicts in their countries

I Department of Political Science, Ekiti State University, Ado Ekiti, Nigeria. E-mail: watermike2003@yahoo.co.uk. 
or at their borders, Africans have been kept in poverty by unproductive and unfair economic systems. They have been left in the hands of fate (and their God) by elites that privatise the State and monopolise the lion's share of economic resources and opportunities. Added to these challenges is the uphill task, particularly in societies such as Nigeria and others with long encounters with military rule and abuse of office generally, of achieving quick economic advancement, prosperity and general economic well-being for ordinary citizens, through democracy (Yagboyaju 2015, I66).

In the light of this, the progressive expansion of poverty, ignorance, hunger, disease, unemployment, exploitation, alienation, oppression and dispossession in Nigeria since independence has continued to influence the resort of Nigerians to a search for the spiritual essence of their being. The socio-economic and political adversities in the country provide a fertile ground for the planting, germination, growth and balkanization of all forms of religion. Thus, the only sector that has been experiencing growth and expansion, nearly six decades after independence, is the religious sector (Jaja 20I6). Religious institutions constitute the widest and deepest expressions of popular participation in Nigeria (USAID 2006, 24) as manifested in being home to the largest number of Anglicans in the world, having the fourth largest population of Roman Catholics and the fifth largest population of Muslims (Okechukwu n.d.).

Thus, in recent times Nigeria has emerged as one of the most religious countries in the world. As the number of churches/mosques in the country continues to increase and the population of worshipers doubles, so also is the number of mosques and Islamic faithful enlarging. It has been argued that Nigeria has become the number one country globally in terms of the population of religion worshipers and adherents, notably of the two major religions, Christianity and Islam (Falana 20I0). The country is now a procreant ground for all kinds of religious movements. From a functionalist perspective, one might argue that religion provides many Nigerians with an identity and a sense of purpose. They also provide a safety net for their followers in the form of food and shelter. This is not unconnected with the fact that, as rightly posited by Nwadialor and Umeanolue $(2013,33)$, the majority of Nigerians have been experiencing abject poverty many decades after independence. The recent socio-economic situation of contemporary Nigeria has been a symptomatic of the endemic plurality of Nigeria's religious landscape.

Nigeria's population size, ethnic diversity, and deepening sense of insecurity - political, economic, cultural, and medical - combine to create a collective experience of anxiety which, in turn, generates a spiralling need 
for religious associations, services, rituals, and solutions. Population growth, urbanization, competition, and the multiple services provided by religious communities make religious associations a significant component of Nigerian social structure. Hence, they are a critical resource for politicians attempting political mobilization on any issue (USAID 2006, 24). Ademola-Olateju (20I5) raises deep posers on this topical issue: In a country where good roads, electricity and healthcare facilities are taken to God in prayer, the link between religion and poverty is worth analysing more closely. Why are poor nations the most religious? Why do poor people cling to religion? Do Nigerians turn to religion due to despair, or do people fall into poverty as a result of their religious beliefs? This essay is, therefore, concerned primarily with the intervention of religious organisations in meeting the spiritual and physical needs of many Nigerian citizens - disenchanted and frustrated as a result of government failure. It examines how religion has become a sanctuary of hope and refuge in the face of daunting socio-economic challenges and how, ironically, this pathetic human condition is being exploited by such religious bodies. It also probes into the state of philanthropy by individuals and corporate bodies in the country within the context of African communalism and governance deficit.

\section{On Government's Primary Responsibilities and the Sobering Realities}

Governments almost certainly originated with the need to protect people from conflicts and to provide law and order. Why have conflicts among people happened throughout history? Many people, both famous and ordinary, have tried to answer that question. Perhaps human nature dictates selfishness, and people inevitably will come to blows over who gets what property or privilege. Or maybe, as Karl Marx explains, it is because the very idea of "property" makes people selfish and greedy (UShistory n.d.). All governments at all levels do have duties and responsibilities to their citizens. The mark and exemplifier of a good government is in the fulfilment of basic duties and responsibilities of such government in Nigeria and worldwide.

Whatever the reasons, governments first evolved as people discovered that protection was easier if they stayed together in groups and if they all agreed that one (or some) in the group should have more power than others. This recognition is the basis of sovereignty, or the right of a group (later a country) to be free of outside interference. Part of a government's function is to protect its citizens from outside attack. Ancient Chinese emperors constructed a "Great 
Wall" to defend the borders of their empire. A country, then, needs to not only protect its citizens from one another, but it needs to organize to prevent outside attack. Sometimes they have built Great Walls and guarded them carefully from invaders. Other times they have led their followers to safe areas protected by high mountains, wide rivers, or vast deserts. Historically, they have raised armies, and the most successful ones have trained and armed special groups to defend the rest. Indeed, in the twentieth century, governments have formed alliances and fought great world wars in the name of protection and order. In more recent years, government responsibilities have extended to the economy and public service (UShistory n.d.).

The Federal Republic of Nigeria emerged as an independent nation from British colonial tutelage in October I960. More than a century of British imperialism and colonialism in Nigeria brought the commanding heights of the Nigerian economy under the control of primarily British, and other Western firms. Gradual implementation of a decolonisation programme granted Nigerian politicians control over regional governments leaving the colonial government with control over foreign affairs, before finally divesting itself of power in I960. Not being active in productive activities, those politicians lacked a solid economic base, and with regional political power in their hands they proceeded to use it to compensate for their lack of a solid resource base. Thus, corruption became paramount in the political affairs of the country (Akude 2007, 9). According to Lewis (2007), Nigeria's travails, while hardly unique within the developing world, are surely exceptional in their scope and persistence. Mass poverty, economic stagnation, endemic corruption, political instability, weak institutions, and social conflict can be found in many countries, and viewed in this light, Nigeria might seem unremarkable.

The relative roles of the three tiers of government - the federal government, the state governments, and the local government authorities (LGAs) - in public service delivery has emerged as one of the most important topics of open and vigorous debate in the new democratic climate in Nigeria. The exclusive responsibilities of the Federal Government of Nigeria are broadly in accordance with standard international practice, including matters of national concern such as defense, foreign affairs, regulation, and monetary policy. The responsibility of service delivery in the areas of education, health, infrastructure, agriculture and industry is concurrently shared with states and Local Government Authorities, with the respective assignments apparently derived from the considerations of inter-jurisdictional spillover effects and economies of scale, although there is no formal reference to the underlying principles in the official literature. 
Section I4(2)(b) of the I999 Constitution of Nigeria states that "the security and welfare of the people shall be the primary purpose of government; and the participation by the people in their government shall be ensured in accordance with the provisions of this Constitution". With respect to the economic well-being of the people, the Constitution has also imposed a duty on the State to guarantee "the maximum welfare, freedom and happiness of every citizen on the basis of social justice, and equality of status and opportunity". To this effect, the State shall direct its policies towards ensuring that "the material resources of the nation are harnessed and distributed as best as possible to serve the common good" and that "the economic system is not operated in such manner as to permit the concentration of wealth or the means of production and exchange in the hands of few individuals or of a group".

In order to ensure good governance and public accountability, the State is under an obligation to abolish "all corrupt practices and abuse of power". Apart from the duty imposed on all citizens to "render assistance to appropriate and lawful agencies in the maintenance of law and order", it is the obligation of the mass media to "uphold the responsibility and accountability of the Government to the people". To eradicate illiteracy and ignorance, the Government shall, as and when practicable, provide "(a) free compulsory and universal primary education; (b) free secondary education; (c) free university education and (d) free adult literacy programme". It is also the duty of the State to protect children, young persons and the aged against any form of exploitation whatsoever and against moral or material neglect (Falana 20I5).

Security of lives and property is a dire need for any thriving country. Without security, a country remains exposed to threats, and is vulnerable. In this state, the attainment of such a country's objectives and projects becomes a herculean task (Iregbenu and Uzonwanne 20I5, I69). As a matter of fact, a government that cannot protect its citizens and guarantee adequate security of lives and property is a failed Government. Without adequate security of lives and property, the system will be rife with lawlessness, chaos and eventual disintegration. This is why security is considered as a dynamic condition, which involves the relative ability.

In Nigeria, as will be discussed shortly, a vast majority of the citizenry are denied basic human needs and this inadequacy has created a "frustration of rising expectations" which in turn resulted in violence, kidnappings, armed robberies, prostitution, terrorism among others. The spate of deaths and destruction associated with religious killings, political violence, ethnic clashes, kidnappings, armed banditry are insurmountable (Omede 20II, 96). 
Amidst the deteriorating security situation in the country, Nigeria is also confronted with daunting developmental challenges which pose serious threat to socio-economic development. These developmental challenges include endemic rural and urban poverty, high rate of unemployment, debilitating youth unemployment, low industrial output, unstable and deteriorating exchange rate, high inflation rate, inadequate physical and social infrastructure, very large domestic debt, and rising stock of external debt (Ewetan 2013). All these are, no doubt, hindrances to good governance in the country.

Good governance has for many years remained elusive in Nigeria's political terrains because of the fact that this worthy aspect of culture, tradition and norms, political vestiges has been abandoned. Rather, despotic and corrupt leaders mostly in uniform have always found their ways into the polity as leaders (Joseph 1987). According to Kukah (cited in Nwankwor 2004, 313), there is a noticeable tendency to trace the performance of democracy as a form of government in Nigeria to the colonial trappings of the state, the nature and character of successive governing elites and their misrepresentation of the purpose of state machinery to the citizenry. Majority of Nigerian leaders since independence, short of rhetorics, have variously shown they have no interest in the future of the country. All Nigeria has to live with are leaders who by some illegal means or the other acquired power, emptied the nation's coffers and restarted the same process by working towards re-election and, where this is not possible, transferred power to their cronies who venture to do worse than their predecessors. They recycled themselves within the corridors of power (Odo 2015).

The main and fundamental problem with Nigeria (and indeed Africa), which has been the country's albatross, rests squarely with bad or poor leadership which cuts across political, religious, traditional, community, ethnic/tribal, labour/union, market and business leaders, as well as other leaders at various levels (military, police and other paramilitary security agencies), who in most cases are always self-serving and self-centred in their approach to handling national issues. Most people in leadership positions either in Government or out of Government - are usually economical with the truth either because of selfish interests or due to corruptive influences or a combination of both (Kayode 20II). Bad leadership manifested by persistent human rights violation, bad governance, dysfunctional institutions, patronage, electoral fraud, manipulation of ethnic differences, corruption and personalisation of power hinder the prevalence of peace and social justice. Powerful political elites feed on the state, prey on the weak, use national resources for self-aggrandizement, and deprive citizens of collective goods 
such as medical care, good education and employment (Burton I990; Sandole 200I cited in Mayanja 2013). According to Adujie (2009):

Nigeria is analogous to a corporation, and our current leaders should be seen as ineffective inefficient managing director and board members. Nigeria is a corporation into which Nigerian citizens are heavily invested. Nigeria should be seen as a corporation which currently has poor return on our investment or no dividends at all. The prudent thing for any smart investor, shareholder to do, in order to earn dividends, profits and return on investment, is to oust the errant managing director and board members.

Over the years, the Nigerian government has failed to harness the vast human and material resources at its disposal to break the cycle of poverty and autocracy that has characterized it since independence in I960. Thus, the Nigerian state has been constantly struggling between the forces of democracy and authoritarianism, and characterized by 'the push for development and the pull for underdevelopment, the burden of public corruption and the pressure of accountability' (Kesselman et al. 1996 cited in Idada and Uhunmwuangho 2OI2, 50). The effect of corruption on Nigeria is, of course, unquantifiable. Aside from soiling Nigeria's corporate image in the international community, all the social, economic and political structures in the country have been ruined by corruption. Social services and infrastructure are in a shambles. The people are pauperized as the ordinary people are always the victims. While the people wallow in abject poverty and want, members of the political class and their business class associates bask in stupendous stolen wealth (The Guardian 20I6).

It is a common practice in most neighbourhoods across the country for residents to be confronted by challenges like broken down transformers, lack of potable tap water, insecurity and so on. The situation has gotten so bad that most Nigerians have resigned themselves to living in a society where paying taxes doesn't guarantee the provision or steady access to basic public amenities (Ogunsina and Opaluwa 20I5). As rightly captured by Segun Quadri (20I5):

Majority of government facilities enjoyed by the masses such as potable drinking water, electricity, good healthcare system, free education etc. are all a story of the past. The common man has even become his own government, providing power, security, water and so on by himself. From I999, since the civilians took over governance under a democratic arrangement, we have suffered progressive deterioration of not only the country's infrastructural network, practically all our 
institutions critical to socio-political and democratic advancement have collapsed. Even governance itself is grinding to a halt.

The poor and disadvantaged suffer in relation to delivery of public services. First, they lack access to those services due to physical, financial, informational, political and other barriers. Second, they lack effective mechanisms for feeding back their complaints, views and requests in relation to those services. As a result, public services to the poor lack transparency, accountability and quality (Gopakumar K et al. 2002). The poor and the disadvantaged are particularly vulnerable as they rely completely on the state for accessing critical services such as drinking water, health and education as enunciated above. Yet, as noted by Diamond (2008), the fundamental purpose of neo-patrimonial, prebendal governments is not to produce public goods roads, bridges, markets, irrigation, education, health care, public sanitation, clean drinking water, effective legal systems - that increase productivity, improve human capital, stimulate investment, and generate development. Rather, it is to produce private goods for those who hold or have access to political power. Contracts are let not on the basis of who can deliver the best service for the lowest price, but rather on who will pay the biggest bribe. Budgets are steered to projects that can readily generate bribes. Government funds disappear into the overseas accounts of office-holders. Government payrolls are swollen with the ranks of phantom workers and soldiers

\section{Philanthropy and Communalism in Nigeria: An Overview}

Africa is a multi-faceted and fascinating continent. With so many different ethnicities and nationalities, one common practice unites all Africans: a culture of giving. Philanthropy, or giving, has long been practiced in Africa. Whether the motivation is to contribute to the growth of the country, give back once business success has been achieved, or support one's neighbours in need, philanthropy serves as the cement that binds communities together and contributes to the development of the continent (Emodi and de Unverhau 20I4, I). Philanthropy is an integral part of the African identity and an inherent characteristic of African family life and community. However, Africans may not recognize the term 'philanthropy', which is a construct of the Global North and is generally associated with the transfer of large amounts of wealth from rich to poor. Many people would use English terms such as 'giving' or 'charity' or 'help' instead (UBS Philanthropy Advisory and TrustAfrica 2014, 32). 
Communalism is the principle or system of social order in which, among other things, the supremacy of the community is culturally and socially entrenched, society is hierarchically ordered, life is sacrosanct, and religion is a way of life. In such a community, people are not seen as important in their own right. Each one is an integral part of the whole, and derives his or her place in the context of the community. People in a communalistic community are born into the community. They are not selected into it. Such a community is not created as a result of the coming together of individuals. It is an evolved community whose membership is hereditary. In a communalistic social order, community welfare undergirds actions. Nothing done, no matter how important and useful it is to the individual, is considered good unless it has relevance for the community. No misfortune, no matter how distinctly personal, is left for the individual to bear all alone. The community laughs together and also cries together (Moemeka I998, I24). Total obedience to the community as an entity that exists for the good of all is demanded not only with respect to physical or material needs, but also with respect to emotional and communication needs. In this setting, religion pervades life in truly communalistic communities (Mbiti I969), and it is used as a tool for safeguarding social order and protecting social norms and communication rules (Moemeka I994). Communalism demands that people's lives reflect a solid blend of what is regarded as holy and what is accepted as socially permissible.

Under communalism, the small community was said to be the main unit of government. Every adult participated both in decision-making and also in the execution of those decisions. Each gave according to his ability. There were communal governments where public decisions were openly arrived at, issues were raised and discussed openly. Decision-making was thus a process of the resolution of views among all the citizens (Oyewole I987, 38).

Nigeria has the region's greatest concentration of High Net-Worth individuals (HNWIs). According to the Nigeria 20I4 Wealth Book, in 2013 Nigeria had over 16,000 HNWIs holding USD 90 billion in wealth. The number of HNWIs is forecast to grow by $7 \%$ to reach over 18,000 in 2018 , while HNW wealth is expected to grow by $27 \%$ to reach USD I23 billion in 20I8. The 20I4 New World Wealth report reflects that Nigeria has 200 Ultra-High Net-Worth individuals, 50 centa-millionaires and four billionaires. Eleven of the HNWIs appearing in the Forbes "Africa's 40 Richest People" in 2012 were Nigerian. Although there is a general belief that the wealth and philanthropy of HNWIs in Nigeria is visible and public, there may be some who prefer to give unseen. In 20I2 Forbes published a list of ten UltraHigh-Net-Worth individuals from Nigeria who prefer to retain a low profile 
(UBS Philanthropy Advisory and TrustAfrica 20I4, 37). Recent literature has sought to highlight the fact that there are different views of philanthropy in Africa (that is, different from how it is seen in other parts of the world), and that very often African philanthropy is characterized by particular practices. There has always been anecdotal evidence to suggest that giving is focused on the extended family and more immediate communities (UBS Philanthropy Advisory and TrustAfrica 20I4, 42). On the flip side, there are concerns about the illusory nature of many of Africa's charitable works, which can appear more like public relations gimmicks than sincere efforts to alleviate problems.

The scene in the contemporary Nigeria is one of general loss of qualms of conscience and utter absence of fear of God and disregard for human life and person, giving rise to general moral decadence and existence of various ills and crimes, such as injustice, bribery and corruption, stealing, armed robbery, killing, kidnapping, rape, cultism etc (Osunwokeh 20I4, I83). Indeed, it is observed that the level of social injustice currently prevalent in Nigeria is reaching alarming proportions. The overwhelming upsurge of militant and resistant groups in Nigeria today are commonly interpreted as demonstrations against the state resulting from the strains of injustice in the system and as signalling the level of discontent amongst the citizenry (Uchegbue 2013, I4I).

Natural resource-rich African countries suffered a severe financial hemorrhage through capital flight over the past decades. Recent estimates suggest that the leakages increased during the resource boom. From I970 to 2008 , Nigeria lost a staggering $\$ 296$ billion to capital flight. About $\$ 7$ I billion went 'missing' from Angola between I985 and 2008 (Ndikumana and Boyce 20II). Other oil-exporting countries also suffered substantial capital flight in the last four decades: Côte d'Ivoire (\$45 billion), the DRC (\$3I billion), Cameroon ( $\$ 24$ billion), the Republic of Congo (\$24 billion), and Sudan (\$18 billion) (Ndikumana and Boyce 20I2, 4). It should be noted that the growth of wealthy individuals does not necessarily lead to an increase in philanthropy and this is very apt in Nigeria. Apart from the formalized philanthropy model - corporate foundations - that exists in the country, wealthy Nigerians, save for a few, do little to use what they have to help the masses. Instead, they transfer their money to foreign banks rather than making it useful for the nation. When these wealthy men want to go on holiday, they travel to United States or Canada, and many migrate to the developed world rather than spend their money in Nigeria.

In the midst of governance failure in the country, Nigerian elites rather live in opulence and splendour, either on their stupendous rentier income, publicly looted funds, or government patronage. A few have indeed 
ranked prestigiously among the richest in the world (Odeyemi 20I3, 26I). Political elites misappropriate considerable public funds for their personal gain, while most of their constituents lack access to potable water. Joseph (20I6) once rhetorically asked: Why can Nigerians build and operate megachurches but not quality public transport, public universities, public energy utilities and other service organizations? Nigeria also illustrates the central dilemma of "Rising Africa": an expanding consumer market and middle class alongside persistent poverty. Inequity in this nation of I75 million is egregious. Many millionaires are spawned as champagne consumption rises and private airplane ownership soars. These excesses, based largely on access to state resources, can be redirected to transformative and sustainable growth (Joseph 20I5). The most frustrating reality is that a larger part of looted public funds is not invested in Nigeria but usually dumped in foreign accounts to further enhance the economies of those states.

\section{How Religion Fills the Vacuum: A Variable for Rescue Mission or Exploitation?}

Nigeria is a multi-ethnic, multi-cultural and multi-religious nation state with over four hundred ethnic nationalities associated with many religious congregations (Aghemelo and Osumah 2009). Nigeria has three major religious identities: Christian, Islam and traditional religions (Omorogbe and Omohan 2005, 557; Osaghae and Suberu 2005, II cited in Çancı and Odukoya 20I6). Traditional religions are the most politically inactive of the three groups, "numbering several hundreds of ethnic groups and sub-groups, villages, clans and kin groups; and, involving the worship of different gods and goddesses' (Osaghae and Suberu 2005, II). The Pentecostal churches form the fundamental division of Christianity in Nigeria which has experienced rapid growth in numbers of followers in the last few years with the majority of adherents, especially the youths, joining the church from the older and more traditional denominations. The church has played an important role in civil society in anti-military struggles and democratisation. This has been made possible through umbrella bodies such as the Christian Association of Nigeria (CAN), the Pentecostal Fellowship of Nigeria (PFN), and the Catholic Bishops Conference (Osaghae and Suberu 2005, II).

Religion is probably the most popular phenomenon in contemporary Nigeria. Religion has achieved this pre-eminence due to its overwhelming impacts and contributions in the Nigerian society. As a notable agent of change, religion has undeniably exerted a great deal of influence positively and 
negatively on the Nigerian people in many ways (Kitause and Achunike 20I3, 5I). The 'failure' of the Nigerian political elite to enact good governments, promote national integration and foster good economic progress via thoughtful and pronounced policies (Çanc1 and Odukoya 20I6) has naturally created a vacuum which the religious bodies are, through their policies/ programmes, filling. Many religious groups make significant contributions to human development, through the provision of education, health and social welfare, mainly for their numerous members all over the country. Beyond the similarity of their social contributions, many religious groups share ideals and virtues, and many religious leaders also share a critique of the Nigerian state and its political class (Nolte et al. 20IO).

Over the past decade, considerable research has emerged that demonstrates the benefits of religious practice within society. Religious practice promotes the well-being of individuals, families, and the community. Of particular note are the studies that indicate the benefits of Religion to the poor (Fagan 2006). Regular attendance at religious services is linked to healthy, stable family life, strong marriages, and well-behaved children. The practice of Religion also leads to a reduction in the incidence of domestic abuse, crime, substance abuse, and addiction. In addition, religious practice leads to an increase in physical and mental health, longevity, and education attainment (Fagan 2006). Yet, research has also revealed a link between the level of poverty and deprivation that exist in a society with the people's religiosity. It is contended that when people are poor they lean on religion for comfort. Ademola-Olateju (20I5), citing other sources, sums up his findings thus:

In a 20I0 Gallup poll of Ioo countries, the data showed a strong, positive correlation between strict adherence to religion and privation. In like manner, an independent study by Dr. Tom Rees, published in the Journal of Religion and Society, showed that in places without strong social safety nets to provide people with opportunities for upward mobility, they are more likely to be religious. When suffering becomes a constant in the lives of people, they are easily consoled by visions of the apocalypse, judgement, punishment and hell. Poverty, deprivation and suffering often leads to consolatory beliefs that the world will soon end, with God rewarding the faithful with everlasting joy where there is no want, no toil, no tribulation. The doom and gloom predictions of the rapture and the trials and tribulations that humanity will face, as found in Christian fundamentalism, is thus made popular. The scenario helps perpetuate suffering by attributing a higher purpose to human pain and suffering as part of God's grand plan for absolution among His chosen. 
Put differently, in the face of the weakness of the Nigerian state and the inefficiency of its institutions to provide the human good to its citizens, the Faith Based Organizations (FBOs) supplement and complement government's efforts towards improving the standard of living of Nigerians. These FBOs in Nigeria which number over 46,000 are involved in propoor, charitable works which alleviate poverty, promote progress, and serve as agents of development (Ogbonnaya 20I2, IO). According to Olarinmoye (cited in Ogbonnaya 20I2, IO):

FBOs in Nigeria provide health and educational services through their hospitals, clinics and maternities, schools and colleges, vocational training centers, seminaries and universities. They own economic institutions, such as bookshops, hotels, banks, insurance, mass media and ICT companies and are prominent owners of real estate in the form of sacred cities and prayer camps which cover thousands of hectares of land. The lands on which their hospitals, schools and orphanages are situated also make up part of their real estate portfolio.

As good governance continues to be found lacking by the majority of Nigerians who live without access to basic public services, other organizations have stepped in to fill the void. Religious organizations now provide a range of social services that government generally provides. These problems are symptomatic of a broader, overarching democracy and governance problem in Nigeria, which relates to an oligarchic control of political power, both formal and informal, by unaccountable political elites (USAID 2006, v). Religious Nigerians from different parts of the country share similar views on good governance and development. These are shaped by recourse to Biblical and Qur'anic ideals of justice, equality and 'the fear of God'. They emphasize the importance of infrastructural development, education and health care for all Nigerians. Many religious groups make efforts to provide their members with access to education and other services. Sometimes their services and facilities are open to members of other religious groups (Nolte et al. 2010).

The other explanation for this development can be located in the tendency of Africans to seek spiritual succour in their religion when all things seem to have failed them including government. According to The Lutheran World Federation (2002, I7), spirituality in African religion is described as "values by which a person individually or in community relates to the spiritual realm" (Mbiti). It is born out of a relationship between human beings and other realities which include God, spirits of the departed, divinities, spirits associated with natural objects and phenomena, and nature itself. Africans are extremely aware of the "triangle of reality" as a community in which they 
participate and to which they belong. Their spirituality is governed by the sensitivity to this reality of relationships and communication.

Beyond the communal life, however, African religion teaches that spiritual powers exist which can shape and influence individual lives, for better or for worse. Therefore, it is important to seek ways and means to manipulate or control those external powers and agencies which are more powerful than humans, through practicing rituals and magical recipes and charms prescribed by religious authorities to those who feel threatened (The Lutheran World Federation 2002, I9). Thus, it is observable in Nigeria to see more patients in religious centres than hospitals (particularly churches) seeking spiritual healing for one ailment or the other; more of desperate job seekers; workers due for promotion; frustrated congregation in need of financial help through divine connection; pregnant women attending special religious sessions rather than antenatal; numerous other problem-induced congregants/worshippers seek spiritual anointing on many anthropic issues like visa applications, life partners, mobility, defeat of enemies among others ${ }^{2}$. This may have informed the submission of Ademola-Olateju (20I5) on the subject matter: Religion offers a sense of hope, and it helps keep the poor from total despair. It thwarts their drive to improve their lot and creates a social disincentive for progress. That is why people under stress are easier targets for evangelism. That is why the soul winning ministries have more success among the poor, and it is the reason they target people going through life-changing events such as illness, marriage, divorce, pregnancy, death in the family, etc. As observed by Larr (2015):

The trouble no longer ends with robbers and kidnappers going to Church every Sunday to pray for God's guidance and assistance in the execution of criminal and murderous projects. It does not end anymore, with criminals paying stupendous amounts as tithes to their gleefully excited and highly gratified pastors and preachers. Nigerians, do have reasons enough to express gratitude to the self-imposed men of God, whose stock-in-trade is flamboyance and the public display of silver and gold and jets and coats. They show us who they are and save for a few gullible and helpless minds, they are known to everyone else for their insatiable greed for material wealth and larceny based on

\footnotetext{
2 This writer has witnessed a lot of these scenes either on research voyage, personal engagement, or invitation by friends and acquaintances. It is usually an unintended transfiguration from empiricism to spirituality in terms of "prayer requests" which ordinarily, in other climes, should be directed to government agencies. Yet, in many instances, people testify to the "power of the Almighty God" in approving these requests! - Obviously affirming an existence between the celestial world (world of God and his angels) and the mundane world (world of the living on earth).
} 
sycophancy. They were not the least, very visible at the seat of power advancing prophetic and treacherously divine justification for all ills and evils in the last political dispensation under the Presidency of Mr. Goodluck Jonathan.

Generally, while religion has contributed in some ways to the process of nation building, the positive impact of religion on Nigeria's democracy has remained negligible. The manipulation of religion by some powerful individuals who hide under the guise of religion to pursue selfish interests remains one of the negative effects of religion on the polity. In addition, greed has crept into the religious terrain to the extent that some religious leaders now patronize corrupt rulers to meet their lust for money and other material gains (Falana 20I0). However, it must be observed that while religious entities and FBOs have assisted with provision of healthcare services, education, etc., as earlier identified, to underserved populations, perhaps based on the perceived moral, benevolent, and religious value of altruism, the religious worldview of Africans and their intense spirituality have often been exploited in an unethical manner. This may explain why Uche (20II) sees a contradiction in the present Nigerian society which he describes as one that is so religious; so rather noisy about church, about the Christian gospel, and yet so morally depraved, witnessing daily in higher proportion, evil and crimes against justice and human dignity. Ironically, beyond the ignorant and the poor, such level of religiosity seems to have captured the educated minds too as posited by Ademola-Olateju (20I5):

Religion in Nigeria has become a powerful open trap that exerts tremendous social pressure that is often impossible for the uneducated mind to avoid. In my interactions, I have seen educated people, who were normal in their homes, normal at work and everywhere outside of the Church, become complete fools once inside the Church. One cannot but wonder if the central problem comes from people turning their minds off once they walk through the door of a Church or Mosque. Their minds seem conditioned to do so since they were young. They swallow anything that is said as the truth. It is no longer what the Bible says but what my Pastor says and for the Muslims, every reference is according to this Sheikh and that Imam.

Essentially, the core principles that formed the underlining foundation on which most religions are based include truth, moral uprightness, love and the unity of all humankind, among others (Falana 20I0). Ideally, instead of impeding sustainable development, religion ought to promote it, because faith addresses the ultimate concerns of human beings and permeates all aspects 
of human life: vital, social, cultural, personal and religious. Religion thus provides an anchor giving meaning to various forms of human experiences, life and actions (Ogbonnaya 2012, I8). Yet, the contradictions embedded in the practice of religion in Nigeria viz-a-viz these values and their supposed attendant transformation of the society remain an interesting study in political sociology as attested to by Ijabla (20I5):

From the professor of medicine who lectures at the prestigious University of Ibadan, to the almajiri destitute who roams the streets of Kano, to the wealthy real estate manager in Port Harcourt, to the lowly nomad of arid Baga, there is one thing that connects these people - religion. Religion permeates every facet of the Nigerian society and influences the collective mindset of its people. Religion supposedly makes people good except that the evidence does not support this claim. What we know is that our society is plagued by all the inequality, injustice and atrocities that one rarely encounters in the godless Scandinavian societies, to use just one example. Our high degree of religiosity has not translated into good governance and prosperity for our citizens.

It can be deduced from the above that the high level of religiosity in Nigeria is nothing more than one of many symptoms of poverty and lack of wellbeing for the vast majority of Nigerians, as it is for other poor countries in the world (Okechukwu n.d). While Nigeria as a whole struggles with the legacy of long military rule and the corrosive effect of its dependence on oil revenue, northern Nigeria has to contend with its geographic weaknesses and a century old, self-imposed isolation from modern education and values. It is against this backdrop that one must observe the spectre of religion and its odious consequences. The harmful effects of religious dogmas and creeds can also be observed in other parts of Nigeria such as Akwa Ibom and Cross River States, where there has been an alarming upsurge in child witch-hunting by evangelical churches, taking advantage of high levels of impoverishment and ignorance (Okechukwu n.d).

In a related development, the menace of materialism in contemporary Christian Churches in Nigeria has become so fertile that most pastors and ministers of the Churches preach prosperity as part of spiritual salvation. It is an often repeated saying that as the human race makes giant strides in science and technology, the tendency is to shift away from religion. However, these days, due to economic hardship and political uncertainties in the society, people appear to be more concerned about using religion to achieve material ambitions. According to Anyaehie (20II), Nigerians only believe in prayers without any physical action whatsoever, which is the result 
of the stagnant growth the country is facing today. The citizens spend most of the time praying for things that need efforts and actions. Kukah (cited in Simbine 20II), a scholar and Catholic priest described the leaders of some of Christian congregations as "pastors scavenging for fortunes in the name of leading souls to God through the organisation of endless spiritual trade fairs called revivals and vigils... hood winking and deducing ordinary citizens away from the culture of hard work and the need to develop a truly Christian ethic to wealth.

\section{Government and Citizen Engagement}

Citizen and civil society engagement to demand and promote good governance can improve overall effectiveness of good governance and anticorruption programs. Increasingly, citizen engagement is no longer a choice for governments (Bhargava 20I4, 6). The extent to which government should be involved in the provision of goods and services that promote citizen well-being is a perennial debate in public policies worldwide. Government is supposed to protect the ability of individuals and social institutions to exercise legitimate authority within their own particular areas of influence without unjust interference from other institutions. It is a truism that, over the years, Nigerians have become deeply frustrated and disappointed over unfulfilled hopes of solving persistent economic crises, social tensions and political instability.

As a new nine-country Pew Research Center survey on the strengths and limitations of civic engagement illustrates, there is a common perception that government is run for the benefit of the few, rather than the many in both emerging democracies and more mature democracies that have faced economic challenges in recent years. In eight of nine nations surveyed, more than half say government is run for the benefit of only a few groups in society, not for all people (Wike; Fetterolf and Parker 2016).

However, this skeptical outlook on government does not mean people have given up on democracy or the ability of average citizens to have an impact on how the country is run. Roughly half or more in eight nations - Kenya, Nigeria, South Africa, the U.S., India, Greece, Italy and Poland - say ordinary citizens can have a lot of influence on government. Hungary, where 6r\% say there is little citizens can do, is the lone nation where pessimism clearly outweighs optimism on this front. Many people in these nine nations say they could potentially be motivated to become politically engaged on a variety of issues, especially poor health care, poverty and poor-quality schools. When 
asked what types of issues could get them to take political action, such as contacting an elected official or taking part in a protest, poor health care is the top choice among the six issues tested in six of eight countries. Health care, poverty and education constitute the top three motivators in all nations except India and Poland3.

The fact that the people directly or indirectly have control of governmental decision is a big factor to the success of democracy. They know that at least they have some say in what goes on, opposed to communist or authoritarian governments where the people have almost no say in decisions. This again helps to create stability within society. It is up to the people to make sure that they voice their feelings to their representatives, so there is no one to blame except themselves if bills or laws are passed that they do not agree within. The fact that the common folk can feel like their thoughts and opinions are heard by people directly involved by the government is an important factor that makes democracy work (Cap 2008). Thus, Institutions and procedures of democracy need to be remedied, especially with regard to competitive, multiparty electoral processes and citizen freedom to exercise their political rights and responsibilities (Gaventa 2006 cited in Mayanja 2013). Ackerman (cited in Mayanja 2013) argues that the 'celebration of free and fair elections is one of the most powerful pro-accountability mechanisms in existence', that ensures that suitable candidates lead the nation. Citizens will express their will and consent on who leads them when the electoral process is not marred by fraud, voter intimidation or persecution of candidates. As rightly canvassed by the then APC Presidential candidate, Muhammadu Buhari (2015) at Chatham House:

It is much more important that the promise of democracy goes beyond just allowing people to freely choose their leaders. It is much more important that democracy should deliver on the promise of choice, of freedoms, of security of lives and property, of transparency and accountability, of rule of law, of good governance and of shared prosperity. It is very important that the promise embedded in the concept of democracy, the promise of a better life for the generality of the people, is not delivered in the breach.

Corruption has a dampening effect on the efforts of any nation to achieve political and economic development. For one thing, corruption reduces investment (Barro 2000) because investors see corruption as an unnecessary

3 These are among the key findings from a new Pew Research Center survey, conducted in nine countries among Io,828 respondents from March 29 to July 9, 2016. 
extra cost of doing business (Lipset and Lenz 2000). It also discourages foreign aid as donor countries grapple with how to ensure that aid money does not end up in private pockets (Nwabuzor 2005, I3I). Similarly, democracy cannot thrive in a country where corruption is pervasive and consistent. Government at all levels should device appropriate strategies to address the menace of corruption in the polity. Citizens and governments around the world are increasingly concerned with, and willing to confront, poor governance and corruption. Fighting corruption in a country requires actions by ministries and agencies in the executive branch of government, independent institutions of accountability as specified in the constitution of the country, and civil society and media. Thus, the effort of the present administration at fighting corruption is commendable even though the menace is ferociously fighting back in all fronts as attested to by President Buhari.

In view of the fact that corruption particularly affects the poorest and most marginalized, who greatly depend on public services, the on-going revelations about public officials who engaged in corrupt practices become worrisome in a country where the societal burdens of an aging population, health concerns, underemployment and unemployment are supported mostly by extended-family networks and the informal sector. It is a truism that corrupt practices and abuse of power, office or privilege undermine the right to an adequate standard of living for every person and his or her family, including adequate food, clothing and housing, and to the continuous improvement of living conditions. As rightly noted by the United Nations $(2007,59)$, corrupt practices divert funding aimed at social services. In this manner, corruption undermines the government's ability to deliver an array of services, including health, education and welfare services, which are essential for the realization of economic, social and cultural advancement.

However, fighting corruption requires a multi-faceted and multidisciplinary approaches and strategies which target its political, economic, legal, administrative, social and moral aspects. This requires coherent, consistent and broad-based approaches with long time perspective. It is argued that fighting corruption is fundamentally about addressing poor governance rather than catching the crooks (Campos and Bhargava 2007). But in a developing country like Nigeria- overwhelmed by decades of corruption and culture of impunity- making culprits to account for their past unlawful deeds, in a very determined and aggressive manner as being witnessed now, seems to conform with one of the expectations of many Nigerians.

This essay recommends four key principles, crucial for developmentaccountability, transparency, participation, and inclusion that have been lacking in Nigeria's governance space. Proponents find in these four concepts 
not just intrinsic value but, just as importantly, a natural instrumental logic. State institutions that are accountable to their people will use their resources constructively rather than misspend or steal them. Greater governmental transparency will allow citizens to determine where their political leaders are going astray and exert well-targeted pressure to put them back on track. Increased public participation in governance processes on the local and national levels will provide those institutions with direct input on how to best respond to citizen needs and bring additional information about blockages and inefficiencies into decision-making processes (Carothers and Brechenmacher 20I4).

Governments quite often failed due to their top-down approach and their inability to consult the citizen, let alone the poor. To remedy this, establishing forums for civil society/state dialogue for monitoring and enhancing the accountability of public services is highly recommended by scholars (Goetz 200I; Paul 2002). There are several good governance outcomes that have been documented when citizen and civil society work together with the state for good governance. These are (i) increased state or institutional responsiveness, (ii) lowering of corruption, (iii) better budget utilization, and (iv)better delivery of public services (Bhargava 20I4, 2). Indeed, evidence is emerging that citizen engagement improves access, responsiveness, inclusiveness, and accountability in the delivery of public services such as health, water, education, and agriculture. It also improves transparency, accountability, and sustainability in natural resources management. Thus, achieving greater accountability by governments, greater transparency by state institutions in their handling of public finances, active participation by citizens in development processes that affect their well-being, or meaningful inclusion of disadvantaged groups in socio-economic life will, no doubt, espouse the fundamentals of government and bring succour to the people.

\section{Concluding Remarks}

Today, Muslim and Christian communities and organisations are publicly questioning the legitimacy of the secular postcolonial state, while at the same time extending their activities in areas of social provision closely associated with the state, but which the state is no longer able to guarantee, such as education and health (Corten and Marshall-Fratani 200I cited in Nolte et al. 2009, 7). As pointed out in this essay, religion holds the promise of liberation from suffering. The promise of refuge and peace in exchange for loyalty and unconditional obedience is almost irresistible under the 
circumstances highlighted here. As the economic and socio-cultural dejection in Nigeria continues to churn out religious faithful, so is the number of clergymen increasing. With continued governance failure in Nigeria, the commercialization of religion and proliferation of religious centres will continue to increase.

Government can influence the cultivation of character and the strength of social bonds by protecting institutions that help to encourage virtue in society, such as the family or religious congregations, against unjust interference from other institutions, including the state. For Nigeria to properly harness its abundant natural resources, large population and market for multinational companies, it must urgently address its pressing national issues. Disputing elites and their various supporters need to be mobilized in order to achieve national integration, value reorientation and development. According to Akude (2007), the failure of the Nigerian state could not possibly lead to its collapse because it takes a conscious action on the part a disgruntled section of a fragmented elite to bring a state to collapse. The Nigerian political elite is still united in the philosophy of personal enrichment through access to state power, and a conscious attack on the state could possibly deny the elite this opportunity.

To advance the democratic project, the Nigerian public needs to gain confidence in its institutions. The public needs to feel that there are organs of the political system that can guarantee fairness and justice and that are not undermined by wealth through corruption. Common citizens must have recourse to democratic institutions in order to express demands and resolve conflicts. At this point, the public has little to no confidence in turning to any branch of the government to help directly resolve problems without the benefit of wealth. A central concern for building democracy in Nigeria is thus to alter this relationship between the oligarchy and the citizenry, so as to reconnect the state to its citizens in a more responsible and responsive manner. Another emerging opportunity arises from the relations within the elite, where democratic institutions and practices are increasingly used for competition within the oligarchy. The starting point for democratization must thus include not only the formal democratic institutions that have been slowly progressing since I999, but also the informal system of oligarchs and their subordinates which overlays the formal institutions of government (USAID 2006, 9).

Civil society organisations and the media have important roles to play in terms of promoting civic education, social dialogue, and providing information that would ensure that the electoral and democratic processes are fair and equitable, and that the elected rulers respond to demands made 
on them by the electorate. In the final analysis, a lot depends on the reestablishment of trust between citizens and their elected representatives, after emerging from a traumatic past, where trust was betrayed and the people were violated. This would require evolving a new culture of democracy in that can guarantee a radical shift from the present pattern of zero-sum politics to new forms of politics that emphasise inclusiveness, social equity and the opening up of the political space for equal participation, representation and choice-making (Norberg and Obi 2007).

Representative democracy needs to modernise itself and actively involve citizens in decision- making processes. Rather than seeing themselves as 'pure' problem solvers, governments, at all levels, should position themselves as the bodies that articulate the issues faced by society, and then strive to create the right environment for private enterprise and academia to find the solutions, providing the necessary data, policies and funding to support these stakeholders. If our elected representatives were to do this, they would restore the public trust and challenge the sense that little of consequence has actually changed in that time (Soto 20I4). Above all else, our leaders must use technology - and their broader expertise - to really understand their citizens' incentives, fears and motivations, and then communicate clearly how considered policies will address these factors. When governments stop being the centre of everything, and the people perceive that they have become the problem solvers, that is when things will change (Soto 20I4).

For African philanthropy, it is still regarded as one of the indispensable means of transforming the continent, in spite of its present worrisome state. For a region that has had more than its share of calamities, philanthropy is a powerful expression of uplifting solidarity. Simply put, it is at the core of the ties that bind one of the most diverse human populations on the planet. Yet, the decline it suffers presently in Nigeria, coupled with governance failure in the last decades, has put majority of Nigerians on the survival lane. However, as noted by Spector (2016), "in this future world, accumulating resources in the hands of the few - whether for alleged social good or private benefit will be recognized as fundamentally unequal, unfair, and unjust". While the government is far from perfect, the resources currently being accumulated by the wealthy few should be redirected into public coffers to build a robust social infrastructure for all (Spector 20I6). It is argued that philanthropy, when conducted as results-oriented, investment activities can improve the quality and quantity of economic opportunities available to citizens. 


\section{REFERENCES}

Ademola-Olateju, Bamidele. 20I5. "Religion as a Tool For Impoverishing Nigerians", Premium Times, November 3.

Adujie, Paul I. 2009. Nigeria at 50: A Re-Examination of Duties and Obligations of Citizenship. http://www.nigeriansinamerica.com/nigeria-at-5o-a-re-examination-of-duties- and-obligations-of-citizenship/

Aghemelo, T. A. and Osumah, O. 2009. Nigerian Government and Politics: An Introductory Perspective. Benin City: Mara Mon Bros \& Ventures Limited.

Akude, John. 2007. "The failure and collapse of the African state: on the example of Nigeria", FRIDE, September.

Anyaehie, M. J. 20II. "Religious Beliefs \& Social Stratification”, Radio duong, April, 4 (2)4.

Barro, R. 2000. "Rule of law, democracy and economic performance". In: G. O. O’Driscoll, K. Holmes, \& M. Kirkpatrick (Eds.), Index of economic freedom. Washington, DC: The Heritage Foundation/Dow Jones Company.

Buhari, Muhammadu. 2015. Prospects for Democratic Consolidation in Africa: Nigeria's Transition. https://www.chathamhouse.org/sites/files/ chathamhouse/field/field__document/20150226BuhariSpeechQA. pdf.

Campos, E. and Bhargava, B. 2007. "Tackling a Social Pandemic”. In: Campos, E and Pradhan, S (eds.), The Many Faces of Corruption: Tackling Vulnerabilities and the Sector Level, World Bank.

Canci, Haldun and Odukoya, O. Adedoyin. 2016. "Ethnic and religious crises in Nigeria: A specific analysis upon identities (I999-20I3)", ACCORD, August 29.

Cap, Adam. 2008. What makes democracy work? https://adamcap.com/ schoolwork/what-makes-democracy-work/

Carothers, Thomas and Brechenmacher, Saskia. 20I4. Accountability, Transparency, Participation and Inclusion: A New Development Consensus? Washington, DC, Carnegie Endowment for International Peace.

Diamond, Larry. 2008. "The State of Democracy in Africa". In: Democratization in Africa: What Progress toward Institutionalization? Ghana Center for Democratic Development, 4-6 October. 
Emodi, Martin \& de Unverhau, Silvia Bastante. 20I4. "Foreword". In: Understanding philanthropy by the wealthy in Africa. https://uhnw-greatwealth.ubs.com/media/7455/ubs-philanthropy-africareport.pdf.

Ewetan, O. O. 2013. Insecurity and Socio-Economic Development: Perspectives on the Nigerian Experience. A lecture Delivered St. Timothy Anglican Church, Sango-Ota, Ogun State.

Fagan, Patrick. 2006. Why Religion Matters Even More: The Impact of Religious Practice on Social Stability. http://www.heritage.org/research/ reports/2006/12/why-religion-matters-even-more-the-impact-ofreligious-practice-on-social-stability.

Falana, Femi. 20I0. Religion and Political Reforms in Nigeria, Being the text of the public lecture delivered at the 5Ist birthday anniversary of Rt. Rev Alfred Adewale Martins, Catholic Bishop of Abeokuta, Ogun State on Saturday June 5 .

. 2015. Insecurity in Nigeria: A Menace to National Development, This presentation was given at the symposium held by the Dentiscope Editorial Board at the University College Hospital, Ibadan, Oyo State on Tuesday, July I4.

Gopakumar, K. 2002. Corruption in South Asia: Insights \& Benchmarks from Citizen Feedback Surveys in Five Countries, Berlin: Transparency International. http://www.transparency.org/pressreleases_archive/2002/dnld/south_asia_report.pdf.

Idada, Walter \& Uhunmwuangho, S.O. 20I2. "Problems of Democratic Governance in Nigeria: The Way Forward", Journal of Sociology and Anthropology, 3(I): 49-54.

Ijabla, Raymond. 20I5. "The Destructive Effects Of Religion On The Nigerian Society”, Sahara Reporters, December 5.

Iregbenu, Paul \& Uzonwanne, Chinecherem. 20I5. "Security Challenges and Implications to National Stability", Journal of Economics and Sustainable Development, Vol. 6, No. 4.

Jaja, Jones. 2016. "Stomach Infrastructure in His Name: A Critique of Pentecostalism”, Elixir Social Studies 95 4III92-4I204.

Joseph, R. A. 2015. “Nigeria’s Renewed Hope for Democratic Development”, AfricaPlus, May 27.

. 20I6. "The Nigerian Prospect: Democratic Resilience amid Global Turmoil”, AfricaPlus, March 3I.

. I987. Democracy and Prebendal Politics in Nigeria: The Rise and fall of the Second Republic. London: Cambridge University Press 
Kayode, Oluwa. 20II. The State of Insecurity and Failure of Leadership. http:// focusnigeria.com/state-of-insecurity.htm

Kitause, Rimamsikwe Habila \& Achunike, Hilary Chukwuka. 20I3. "Religion in Nigeria from 1900-2013", Research on Humanities and Social Sciences, Vol.3, No.I8.

Larr, Frisky. 20I5. Of Pharisees And Cardinals In The Buhari Equation. http:// gadoar.com/post/90327-of-pharisees-and-cardinals-in-the-buhariequation-by-frisky-larr.

Lewis, Peter. 2006. "The Dysfunctional State of Nigeria”. In: Birdsall Nancy et al (eds.) Short Goal of the U.S. Policy and Poorly Performing States, Center for Global Development.

Lipset, S. M., and Lenz, G. S. 2000. "Corruption, culture and markets”. In: L. E. Harrison \& S. P. Huntington (Eds.), Culture matters, New York: Basic Books.

Mayanja, Evelyn. 20I3. "Strengthening ethical political leadership for sustainable peace and social justice in Africa: Uganda as a case study", ACCORD, July I2.

Mbiti, ]. S. I969. African religions and philosophy, London: Heineman.

Moemeka, Andrew A. I994. Socio-cultural dimensions of leadership in Africa. Paper presented at the Global Majority Retreat, Rocky Hill, CT.

. I998. "Communalism as a Fundamental Dimension of Culture", Journal of Communication, Vol. 48, No. 4.

Ndikumana, Leonce and Boyce, James. 2012. "Rich Presidents of Poor Nations: Capital Flight from Resource-Rich Countries in Africa", Association of Concerned Africa Scholars, Bulletin N $87-$ Fall 2012

Nolte, Insa; Nathaniel Danjibo \& Abubakar Oladeji. 20Io. "Religion, Politics and Governance in Nigeria, Birmingham, Religions and Development Research Programme Working Paper 39. http:// www.rad.bham.ac.uk/files/ resourcesmodule/@random454f8of6ob3f4/1269512095_working_paper_39_for_the_web___2__2_. pdf.

Norberg, Carin and Obi, Cyril. 2007. Reconciling Winners and Losers in Post-Conflict Elections in West Africa: Political and Policy Imperatives. http://www.diva-portal.org/smash/get/diva2:240865/FULLTEXT02.pdf.

Nwabuzor, A. 2005. "Corruption and development: New initiatives in economic openness and strengthened rule of law". Journal of Business Ethics, 59(I), I2I-I38. 
Nwadialor, L. Kanayo and Umeanolue, Ikenna L. (n.d) Materialistic Gospel Message in Contemporary Nigerian Churches: A Critique

Nwankwor, I.J. 2004. "Consolidating Democracy in Nigeria: A Philosophical Prognosis". In: Onuoha, J. and Okpoko, P.U. (eds.) Ethnic Nationalism and Democratic Consolidation: Perspectives from Nigeria and the United States of America. Nsukka: Great AP Express Publishers Ltd. Pp. 309-320.

Odeyemi, Oluwole Jacob. 2013. Elite-Priesthood Connivance in Nigeria: Implications for Security and Development, JORIND II(2) December.

Odo, Linus. 20I5. "Democracy, Good Governance and Development in Nigeria: The Challenges of Leadership", Journal of Humanities and Social Science, Volume 20, Issue 6, Ver. III.

Ogbonnaya, Joseph. 20I2. "Religion and Sustainable Development in Africa: The Case of Nigeria", International Journal of African Catholicism, Vol. 3, No. 2.

Ogunsina, Bukola and Opaluwa, Timothy. 2012. When Citizens Take Over Duties of Government, Leadership Jul II.

Okechukwu, Ikechukwu (nd) Religious Creeds and Dogmas in Nigeria. http:// africaunbound.org/index.php/aumagazine/issue-7/item/religious-creeds-and-dogmas-in-nigeria.html

Omede, A.J. 20II. "Nigeria: Analysing the Security Challenges of the Goodluck Jonathan Administration", Canadian Social Science Vol. 7, No. 5, pp. 90-IO2.

Osaghae, E \& Suberu, T. 2005. "A History of Identities, Violence, and Stability in Nigeria", Oxford : Centre for Research on Inequality, Human Security and Ethnicity ((CRISE), Working Paper No. 6. January

Osunwokeh, Clement. 20I4. "Bible Interpretation, Evangelization and Faith: Nigerian Context", Open Journal of Philosophy, 4, I82-I9I.

Oyewole, A. I987. Government: For Senior Secondary School. Ibadan: Onibonoje Press and Books industries (Nig) Ltd.

Paul, Samuel, 2002. The state of India's public services: benchmarks for the new millennium. Bangalore: Public Affairs Centre. http://www.worldbank.org/participation/spaulısApril.pdf.

Simbine, A.T. 20II. Religion, Ethics and Attitudes Towards Corruption in Nigeria. Ibadan: SGPRD, NISER 
Spector, Jessie. 20i6. "The Game Changer",in The Future of Philanthropy, The Nation, July 2I.

Soto, Jorge. 20I4. The weakening of representative democracy. http://widgets. weforum.org/outlooki5/05.html.

The Guardian Editorial. 20I6. As corruption fights back, December 5.

The Lutheran World Federation. 2002. Crises of Life in African Religion and Christianity, LWF Studies. https://www.lutheranworld.org/sites/default/files/DTS-Studies_Crises_of_Life-200202.pdf.

UBS Philanthropy Advisory and TrustAfrica. 20I4. Understanding philanthropy by the wealthy in Africa. https://uhnw-greatwealth.ubs.com/ media/7455/ubs-philanthropy-africareport.pdf

Uche, C. 20II. "The Witness of Life: A Challenge to the Catholic Priesthood in the 2ist Century". In: J. O. Oguejiofor, \& A. C. Oburota (Eds.), Challenges of Priest in the Century. Enugu: Bigard Press

Uchegbue, Christian Onyenaucheya. 2013. The Place of the Church in the Socio-Political and Economic Liberation of Nigeria, Proceedings of the Ist Annual International Interdisciplinary Conference, AIIC 20I3, 24-26 April, Azores, Portugal.

United Nations. 2007. Good Governance Practices for The Protection of Human Rights, Office of The United Nations High Commissioner for Human Rights, United Nations, New-York and Geneva.

USAID. 2006. Democracy and Governance Assessment of Nigeria, United States Agency for International Development.

UShistory. n.d. American Government "The Purposes of Government". http://www.ushistory.org/gov/ra.asp

Wike, Richard et al. 20I6. Even in Era of Disillusionment, Many Around the World Say Ordinary Citizens Can Influence Government, PewResearchCenter, October 24.

Yabi, Gilles. 20I5. What Type of Democracy Does Africa Need? http://www. osisa.org/openspace/global/what-type-democracy-does-africa-need.

Yagboyaju, Dhikru Adewale. 2015. "Nigeria's Fourth Republic (I999-2015) and Electoral Outcomes: How long can Patronage or 'Politics of the Belly' Last?” Journal of African Elections, Volume I4, No 2. 


\section{ABSTRACT}

Religion plays a huge role in many societies around the world and this is especially true in Nigeria. Many of the religious groups in the country are united by their critique of the failure of the Nigerian Federal and State governments to deliver welfare to citizens. Thus, as good governance continues to be found lacking by the majority of Nigerians and in the face of the weakness of the Nigerian state and the inefficiency of its institutions to provide the human good to its citizens, religious organizations now provide a range of social services for their numerous members all over the country. How do wealthy Nigerians give and what is their motivation? Is traditional African philanthropic gesture (communalism) fading away in Nigeria? This essay is therefore, concerned primarily with the intervention of religious organisations in meeting the spiritual and physical needs of many Nigerian citizens - disenchanted and frustrated as a result of government failure. It examines how religion has become a sanctuary of hope and refuge in the face of daunting socio-economic challenges and how, ironically, this pathetic human condition is being exploited by some religious leaders. It also probes into the state of dwindling philanthropy by individuals and corporate bodies in the country within the context of African communalism.

\section{KEYWORDS}

Government; Religion; Philanthropy; Human Development; Citizen.

Received on March 3, 2018. Approved on June 6, 2018. 